\title{
Policy Learning in the Development of Bologna Study Cycles in Ukraine
}

\begin{abstract}
This article investigates how policy learning could be used as an analytical tool for studying the development process of Bologna study cycles (Bachelor's, Master's and Doctorate's or $\mathrm{PhD}$ ) in the Ukrainian higher education context. The development of the Bologna study cycles in Ukraine are associated with the fact that Ukraine joined the Bologna process. The findings show that the Bologna study cycles in Ukraine have been developing on the basis of the old national education-qualification and scientific cycles through a so-called process of layering of minor innovations. This layering has been quite productive as it was exercised jointly by multiple policy actors.
\end{abstract}

Key words: policy learning, layering, Bologna, study cycles, Ukraine

\section{Introduction}

A clear emphasis on policy learning in the policy literature emerged in the 1980s, stemming from 'a cognitive turn in policy analysis' (Borrás, 2011, 726). Around two decades ago, it was predicted that policy learning was 'on the verge of becoming a key element in contemporary theory ...of policy making' (Hall, 1993, 276). Policy learning has gained momentum in the literature by drawing the attention of many scholars (e.g., March and Olsen, 1989; Freeman, 2007; Zarkin, 2008; Radaelli and Dunlop, 2013). It remains a contested concept subject to ongoing exploration.

This article applies policy learning to the study of education policies and investigates how policy learning could be used as an analytical tool for studying the development process of the Bologna study cycles in the Ukrainian higher education context. The development of the Bologna study cycles in Ukraine started after Ukraine joined the Bologna process - an intergovernmental European project for the convergence of higher education structures in the countries that are part of the European Higher Education Area (Corbett, 2011).

The article starts with the review of how policy learning has been theorised in the literature and what definition of policy learning can be inferred from this review. Then, the context of the development of study cycles in Ukraine is presented and empirical methods for this research are outlined. The findings about the development of study 
cycles in Ukraine are then presented and discussed in association with the definition of policy learning induced from the relevant literature review.

\section{Features of the policy learning process}

There is a terminological diversity among scholars who study similar policy processes, such as learning, transfer, translation, diffusion (Marsh and Sharman, 2009). Three main perspectives on the relationship between policy learning and other policy processes can be singled out based on the analysis of relevant literature.

First, policy learning is seen as a component of some bigger process of policy change. In particular, learning along with borrowing are believed to constitute a two-fold nature of transfer, according to Steiner-Khamsi (2002). Similarly, learning is seen by Marsh and Sharman (2009) as one of four mechanisms of policy transfer and diffusion. The other three mechanisms, according to these scholars, are: competition, coercion and mimicry.

Second, policy learning is also approached as a process that has equal weight to other processes. Learning is, for example, positioned alongside diffusion, transfer and translation, and it is claimed to be interdependent with them (Lange and Alexiadou, 2010; Stone, 2012). In addition, there have been recent attempts to integrate the notions of policy learning and transfer based on their similarities (Borrás, 2011). The similarity of learning and borrowing in education policy is highlighted by Lingard (2010) and Chakroun (2010). The authors claim that the two processes go hand in hand, as learning shapes borrowing to adapt the policies that are borrowed.

Finally, policy learning is viewed as an umbrella term for all other policy processes. Specific examples of this idea are the claims that policy learning involves transfer (Grin and Loeber, 2007), and that learning is a source of diffusion (Heikkilla and Gerlak, 2013). There are also general arguments such as the one by Zarkin (2008) and Levin (2010), who state that all policy-making processes are associated with policy learning. While most of the literature dwells on the technicalities of the learning process, Levin (2010) evaluates the benefits of cross-country policy learning in the area of education and claims that it does not always result in positive outcomes - 'analogies to disease and epidemics may be a useful way of thinking about what is happening' because reforms are often promoted for the sake of reforms (p.131).

There are, of course, some sceptics who do not subscribe to the all-encompassing policy learning perspective - that everything in a policy context represents learning in some way. Thus, the identification of the limits of learning became a priority for some authors. They argue that mimicry and copying do not involve learning (May, 1992; Heikkilla and Gerlak, 2013). However, other authors argue that absolute copying and 
mimicry are not plausible in practice because different contexts shape the implementation of the same policy differently (Steiner-Khamsi, 2004; Peck, 2011). The lack of evidence of what can be regarded as learning, supports the perspective that learning is associated with many other policy processes, and that learning plays the central role in the policy context.

Definitions of policy learning often rely upon an everyday understanding of the word learning, which is associated with schooling or other training. So, a learning process is commonly understood to be the acquisition of knowledge and skills in some area. While this might be true and applicable to policy learning, such an understanding is superficial. Learning in the policy context is a much more nuanced phenomenon, and the importance of its definition should not be overlooked.

There is literature that does define policy learning. For example, policy learning is described as a 'tendency for some policy decisions to be made on the basis of knowledge and past experiences and knowledge-based judgments as to future expectations' (Bennett and Howlett, 1992, 278). In a second example, policy learning is a sequence of '...relatively enduring alternations of thought or behavioural intentions that result from experience and/or new information and that are concerned with the attainment or revision of policy objectives' (Sabatier and Jenkins-Smith, 1999, 123). These definitions demonstrate that the main idea of policy learning is updating policy ideas on the basis of the association of new information and pre-existing knowledge. The combination of both presupposes the preservation of something that existed before - 'the old', and the introduction of innovations - 'the new'.

How 'the old' and 'the new' come together may follow different paths and result in a different emphasis at different stages of the policy learning process. Schmidt (2010) suggests that this could be explained by four institutionalist frameworks, or frameworks of institutional policy learning. First, rational choice institutionalism views policy actors as rational, pursuing their preferences within the incentivised environment of the institutions. Second, historical institutionalism emphasizes 'the development of political institutions, described as regularized patterns and routinized practices subject to a "logic of path-dependence" ' (p.2). Third, sociological institutionalism focuses on 'socially constituted and culturally framed rules and norms' that guide learning in institutions (p.2). Finally, discursive institutionalism explains 'the substantive content of ideas and the interactive processes of discourse in institutional context' (p.2).

Historical institutionalism with its emphasis on path-dependency seems to be the most suitable to explain the case of the development of the Bologna study cycles in Ukraine as evidenced later in the article. Path-dependency is a dynamic process, which is primarily governed by its own history. It induces establishments to resist sudden wholesale changes (Haas, 2004). Path-dependency is commonly explained with the help 
of an example of the QWERTY keyboard - the standard English language computer keyboard. This device is resistant to transformations largely because of the impossibility to incrementally rearrange the layout of keys (Koch et al, 2009). For instance, changing the layout of the keys would mean swapping over the keys, but keeping the old keys in the keyboard. Despite the special rearrangement, the same keys remain because of the established alphabet, numbers and other conventional keys. Similarly, policy contexts are resistant to change because of certain pre-ordained structures. A determining role of the past in policy settings is advanced by a number of scholars. For instance, Hall (1993) claims that the policy context responds 'less directly to [current] social and economic conditions than it does to the consequences of past policies' (p.277). Likewise, Cairney (2011) states that a policy process particularly in the area of education is 'more about dealing with the legacies of past decisions than departing incrementally from them' (p.214).

Thelen (2003) takes the discussion of path-dependency further to explain incremental changes that eventually accumulate. This author sees path-dependency as one of the two subsidiary processes, along with incremental change. So, path-dependency and change may be intertwined in an overarching process called layering in which changes are accumulated on the basis of some of the conventions that were initially left unchanged (Thelen, 2003). Layering may be a more productive tool for analysing the development of Bologna study cycles in Ukraine. Layering, as an analytical tool linked to pathdependency, relies on the ideas of historical institutionalism.

Layering may then be viewed as a form of policy learning with a few important characteristics that are discussed in the literature. This literature states that policy learning is a productive process exercised by multiple policy actors. It is, therefore, collective.

Policy learning represents a combination of contributions from different policy actors - thus, it has a shared nature. Such shared, or in other terms - collective, distributed governing, is 'more cooperative mode where state and non-state actors participate in mixed networks' (Enders, 2004, 372). This is the case particularly in European education policy-making, as international actors often set the tone and national governments seek alignment to cooperate in the development of their respective national policies (Raffe and Semple, 2011; Alexiadou, 2014).

Policy-makers learn jointly (and work) as so-called bricoleurs because they 'piece together' information from different sources to develop policies (Freeman, 2007). Besides policy-makers, the literature also recognises practitioners as active participants in policy learning, and contributors to the development of policy ideas. For instance, the practice of policy might be often steered by what Cairney (2011) calls 'street-level bureaucracy' (p. 214). It stands for a shift in policy-makers' ideas when exercised by practitioners. Such a conceptualisation of policy learning partially blurs the line between policy-makers and 
practitioners. So, policy learning is not an abstraction that precedes the implementation of policy in practice - policy is something that is continuously shaped.

Policy learning is a productive process. More specifically, Freeman (2006) states that 'Policy does not exist somewhere else in the finished form, ready to be looked at and learned from, but it is finished or produced in the act of looking and learning. Learning is the output of a series of communications, not its input; in this sense it is generated rather than disseminated' (p. 379). The author further argues that policy learning 'is not simply an interpretation act, a process of registering and taking account of the world; it is, in a fundamental way, about creating the world' (p. 382). Consequently, the meaning of policy may emerge through learning.

Policy outcomes at any stage of the policy learning process may be compared differently to the initial goals. The outcomes may closely match the goals, following policy actors' measures taken in the framework of 'a rational-purposive model' (Trowler, 2001, 1). Alternatively, there may be 'loose coupling' between the two (Trowler, 2001, 3). The 'loose coupling' might be generated with a specific purpose, or it might just happen in the swirl of multiple activities running at the same time (March and Olsen, 1989). Purposeful (intended) diversion away from the declared by concealing real political goals or changes under a different label in the first place is termed as 'window dressing' (March and Olsen, 1989).

In any case, policy learning is productive also because policy actors may have to deal with uncertainty at any point of the policy learning process. Ambiguity is always the case in policy learning because actors find it difficult to evaluate potential outcomes of previously untried alternatives (Radaelli and Dunlop, 2013). Policy learning has been characterised as 'collective puzzlement' (Hall 1993, 275). The degree of uncertainty defines how active policy actors are in their search for new knowledge. So, the higher the uncertainty, the more active policy actors are in new information acquisition, and the less likely they are to wait for knowledge to be produced and passed to them by external sources (Zarkin, 2008). More specifically, a peak point of national internal puzzlement, which countries experience at a particular time, makes an important incentive for the national policy actors to engage in learning from the international environment (Steiner- 
Khamsi, 2006; Burch, 2007). The appearance of such an incentive is associated with the 'tipping point' for change (Marsh and Sharman, 2009, 269), described earlier.

So, policy learning may be viewed as a process that unfolds through the fluidity between path-dependency and innovations that shape each other. Path-dependency and change become interlinked through collective and productive layering.

\section{Brief context - study cycles}

This article explores how policy learning could be used as an analytical tool for studying the development process of study cycles in Ukraine. This development process has been taking place for a long time. It intensified in the last decade because Ukraine joined the Bologna process - intergovernmental European project since 1999 for the convergence of higher education structures in the countries that are part of the European Higher Education Area. This convergence has been planned and implemented on a number of ways, such as a common system of credits and cycles of study process, the development of an easily readable diploma supplement issued to graduates, the promotion of student and faculty mobility and the assurance of higher education quality (Corbett, 2011).

Cycles of study process are the focus of this article. It will be demonstrated below that in the framework of the Bologna process, Ukraine has been working on narrowing down its multiple cycles to a three-cycle system that would include only Bachelor's, Master's and Doctorate's (or PhD) cycles.

Ukraine officially joined the Bologna process in 2005 (The Bergen Communiqué, 2005), but had started the work on the implementation of the Bologna study cycles earlier. The Ministry of Education and Science organised in the 2004-2008 Bologna pilot project in Ukraine ('Ministerial decree №48', 2004). This pilot project presupposed mainly the introduction of the credit system and a system of the Bologna study cycles at a selected number of universities, along with some other minor policy innovations. Although one of the goals of the pilot project was to implement the Bologna system of study cycles, this article will demonstrate that this process continued further afterwards and was strongly dependent on the older policies associated with cycles.

\section{Methodology}

The empirical part of this study aimed to investigate how the Bologna study cycles in the Ukrainian higher education context developed. Two main methods of data 
collection were used for this: policy document search and conducting interviews with policy actors. 14 documents were collected and 4 in-depth interviews were conducted (see Appendix 1). Most of the data used in this study were collected in November-December 2013. However, one document - 'Law about Higher Education' (2014) - was collected a year later. This Law was passed after the main data collection had been finished, but it was very important for the analysis given its legislative power.

The purposive sample of policy documents included six Bologna international policy documents that were used by Ukrainian policy actors as guidelines; four Ukrainian laws, three of which were issued before Ukraine joined Bologna; and four decrees of the Ministry of education and Science of Ukraine.

Interviews were conducted with individuals who had cross-membership in establishments that played a great role in the implementation of Bologna action lines, particularly study cycles. The four interviewees represent the following establishments:

- a working group at the Parliamentary Committee of Education and Science Matters, Bologna Follow-up Group

- two civil sector (non-governmental) organisations (National TEMPUS Office, Fund Demokratychni Initiatyoy)

- one expert team (Higher Education Reform Experts)

- two higher education institutions.

Policy documents and interviews were coded manually and analysed thematically. Thematic coding involves reading through transcripts to identify broad codes and then rereading the transcripts to specify the codes (Rubin and Rubin, 2012). This could be associated with open coding - the first of two stages of coding (Blaikie, 2000; Merriam, 2009). It entails breaking down the data into categories and sub-categories while being open to different insights. Open coding was done around the questions: 'what was developed in terms of the study cycles', 'who participated in this process', 'when did the developments take place', 'why did they take place' and 'how did they take place', following Dolowitz and Marsh's (2000) suggestion for a multi-faceted investigative approach to the study of learning in policy. A number of categories and sub-categories were identified under each of the five questions, such as different types of policy actors that participated in the development of the study cycles in Ukraine; different cycles, their definitions; the chronology of the emergence, renaming, change of the cycles, etc. The idea of path-dependency prompted the coding to refer to both the time before Ukraine joined the Bologna Process as well as afterwards - to be able to later trace whether there was any 
'foundation' on which innovations were built on. The codes for the 'what' and 'when' questions were particularly important to trace these innovations.

The second stage of coding - called axial or analytical coding (Rubin and Rubin, 2012) - was conducted by reading through the codes multiple times to reveal relationships between categories and sub-categories. These relationships usually depend on a variety of issues such as context, interview conditions, etc. (Blaikie, 2000; Merriam, 2009). In this study, these relationships among the categories obtained after the open coding were primarily shaped by the theoretical framework rooted in the idea that path-dependency and layering may play a key role in the process of policy learning. The categories from the open coding were regrouped in the axial coding, consequently highlighting the nature of path-dependency and layering in this case.

\section{The development of the study cycles in Ukraine}

Study cycles is a Bologna policy instrument which was developed on the basis of related national policies. The higher education actors in Ukraine first renamed the old national education-qualification and scientific cycles of studies 'study cycles'. These actors have gradually changed the old policies according to the guidelines on the international scale. A two-cycle system was first promoted internationally and nationally in Ukraine before a three-cycle system was recognised at the international ministerial conferences to be the priority.

The Bologna study cycles in Ukraine have been developed in a similar way to the system of credits. The system of the Bologna study cycles was primarily shaped by providing new labels to old structures, and by making minor changes in other old structures.

\subsection{The old education-qualification cycles and scientific cycles}

Before the Bologna process, Ukraine used to have education-qualification cycles (Kremen et al, 2006). The education-qualification cycles included Junior Specialist's, Bachelor's, Specialist's and Master's cycles that led to corresponding degrees ('Law about Education,' 1991, chapter 2, article 30; 'Law about Higher Education,' 2002, chapter 2, article 6). The two scientific cycles led to the following degrees: Candidate of Sciences and Doctor of Sciences, ('Law about Education,' 1991, chapter 2, article 31; 'Law about Higher Education,' 2002, chapter 2, article 18).

The 'Law about Higher Education' (2002) demonstrated an attempt to define the education-qualification cycles (chapter 2, article 8), unlike the earlier 'Law about Education' (1991). This attempt was unsuccessful because the definitions of the cycles 
were similar, and thus, did not explain differences among the cycles. For instance, Junior Specialist's was the cycle of studies to acquire 'certain skills and knowledge, which are sufficient for the functions of production in a certain cycle of professional activity.' This cycle led to the Junior Specialist's degree which was 'uncompleted higher education.' Bachelor's was the cycle of studies to acquire 'fundamental and specific skills and knowledge... sufficient for fulfilling tasks and responsibilities (jobs) of a certain cycle of professional activity.' This cycle of studies led to the Bachelor's degree which was 'basic higher education.' The definitions of other education-qualification cycles revolved around similar vague ideas.

The 'Law about Higher Education' (2002) specified the procedure of access among these cycles. Studies at all consequent cycles could be undertaken by students, but not all the cycles were mandatory to access the highest education-qualification cycle-Master's. It could be accessed after the completion of either Bachelor's or Specialist's. Specialist's could be accessed after finishing Bachelor's. Junior Specialist's did not have to be completed to access Bachelor's. In general, a prerequisite for accessing higher cycles was a completion of a lower mandatory cycle in 'the same or related specialty' (Law chapter 2 , article 8).

With regard to the scientific cycles, both Laws just mentioned them without really defining them. A reason for the scientific cycles to be left out from the 'Law about Higher Education' (2002) was discussed by Talanova (2014). The author argued for a historical separation of higher education and research in Ukraine and mentioned that scientific cycles were regulated by the 'Law about Scientific and Scientific-Technical Work' (1992). My reading of this Law revealed that the cycles which led to the degrees of the Candidate of Sciences and Doctor of Sciences were Aspiratura and Doctorate's, respectively. Additionally, the Law stated that the access to the latter degree was conditional upon a successful completion of the former one (Law chapter 3, articles 19, 20). Ironically, comprehensive definitions of either of the degrees or cycles leading to them were absent. Talanova (2014) emphasised that the legislature of Ukraine did not explain how the scientific cycles were related to the education-qualification cycles. The author found it problematic because research was detached from higher education in all educationqualification cycles. Scientific cycles were related to higher education only by the fact that they could be acquired at higher education institutions in addition to research institutes.

\subsection{The two-cycle study system}

The national education-qualification and scientific cycles were associated by the Ministry in its decrees with the Bologna idea of the study cycles. The participants of the Bologna conference agreed that undergraduate and postgraduate studies made the two parts of the two-cycle system. The two-cycle system was associated with the undergraduate Bachelor's cycle and the postgraduate cycle which, at first, denoted both 
'Master's and/or Doctorate's' ('Bologna declaration,' 1999, 3).

The introduction of the two-cycle system was among the targets of the Bologna pilot in Ukraine ('Ministerial decree №48,' 2004 and '№49,' 2004). However, no particular explanations were provided in the decrees about how the system was to be implemented. The only exception was a reference that Specialist's and Master's degrees belonged to the second cycle ('Ministerial decree №48,' 2004). It remained unclear where other structures fell. However, the reference about the second cycle showed that the implementation of the two-cycle system was sought through relating the old structures and the new cycles.

\subsection{The three-cycle system}

The relationship between Master's and Doctorate's degrees did not change at the international ministerial conferences until after the Berlin Conference (2003). It is stated in the communique of this conference that 'First cycle degrees should give access... to second cycle programmes. Second cycle degrees should give access to doctoral studies' (p. 4). Obviously, the statement suggests that the Doctorate was not regarded as the second cycle any longer. However, it was not explicitly identified as the third cycle back in 2003. That was why, perhaps, the Ministry of Education and Science of Ukraine referred to the two-cycle system at the beginning of the Bologna pilot project. A Doctorate's degree was recognised internationally as the third cycle in 2005. This change occurred at the meeting of the international BFUG Working Group on the Third Cycle in Salzburg in 2005. The BFUG developed a list of the so-called Salzburg principles. They stated, for instance, that the third cycle is the $\mathrm{PhD}$. It should last from three to four years and presuppose conducting original research ('Salzburg Principles,' 2005). The third cycle was later recognised at the Bergen conference ('Bergen Communiqué,' 2005).

The earlier attempt of the Ministry to fit the old education-qualification cycles into the cycle system was preserved. The education-qualification and scientific cycles were decided by the Ministry to be the basis for the representation of the Bologna three-cycle study system in Ukraine. For instance, the national implementation report of 2007 noted that the Bologna three cycles of studies had been implemented in Ukraine. This claim was perhaps made on the basis of the 'Ministerial decree №612' (2007), which mentioned the necessity to improve the three-cycle system in Ukraine. However, it was unclear how exactly all Ukrainian structures were to fit into the three cycles, and how to justify the multiple degrees within each cycle.

The Ministry appears to have been ignoring the fact that too many degrees existed in Ukraine. For example, the Minister of Education and Science made a request to certain units within his Ministry, as well as the Ministry of Labour, the Ministry of Justice, the Ministry of Economics and 'other interested central bodies of executive branch.' The Minister requested them to 'develop measures aiming at a gradual implementation of the 
three-cycle system (Bachelor's, Master's and Doctorate's cycles), considering the national context and a possibility of the existence of interim qualifications' ('Ministerial decree №612,' 2007). In fact, the decree did not ask to change anything in what had been already established in terms of the cycles of studies in the Ukrainian higher education. The reason behind this process of seemingly ignoring the problem by the Ministry is explained by an ex-representative from the central governing bodies who discussed the case of the Specialist's degree:

The difference between the programmes for Specialist's and Master's is in two-three courses. These degrees are very similar, in fact... The "Law about Higher Education" [2002] does not really specify the difference between the two degrees. Well Master's is higher. Nevertheless, both degrees can be undertaken after Bachelor's. Both are around one year long. Both require a dissertation to be written... We need to get rid of Specialist's. However, if we liquidate Specialist's, people who obtained this diploma earlier will come to employers, and what? They need some additional piece of paper that would make them equal to those who have Bachelor's. However, it would mean abusing their rights because those who obtained Specialist's studied one year more than Bachelor's). Otherwise, we would need to make them equal to Master's. However, we do not have the right to do so either. How can we do this if graduates with the Specialist's degree have not studied in the same way that those with Master's did? So we would have to organise a system of qualification upgrading. This is millions of people. For what money? Thus, there is a conscious procrastination - not ignorance (i.3, ex-representative of a working group at the Parliamentary Committee of Education and Science Matters, ex-representative of the BFUG, current academic manager at a university).

The establishment of correspondence among the study cycles in Ukraine and the three Bologna cycles had been postponed for a while by the central governing bodies. Meanwhile, some steps were taken by the representatives of other clusters to develop the Bologna study cycle instrument. These changes pertained to the cross-programme access among the cycles and the equation of one research cycle in Ukraine to the Bologna PhD cycle.

The impossibility of cross-programme access among the cycles was preserved for a long time in Ukraine. This was in spite of the necessity to ensure that such access was recognised at the international ministerial conferences ('London Communiqé' 2007). The difficulty in the cross-programme access from Bachelor's to either Specialist's or Master's in Ukraine is mentioned in the international 'Stocktaking Report' (2012). It is also discussed by a civil sector representative:

The Ministry prohibited applying to a different study area after completing a degree in another area. If you study, for example, Political Studies for your Bachelor's, you cannot apply for a Master's programme in Sociology... The same is with this Specialist's degree and with the 
Candidate of Sciences... You cannot write a thesis, for example, in Sociology if you have a background in Geography (i.4, representative of the Fund Demokratychni Initiatyvy).

The debate around the problem with the cross-programme access was gaining momentum. It was even raised at the meetings of the cross-cluster team of the HEREs:

We knew about the problem and we brought it up at the meeting of our team because the meeting included important and influential people - people from the Ministry (i.1, representative of the team and a university instructor).

These discussions prompted the Ministry to start a pilot in cross-programme access ('Ministerial decree №548,' 2013). The pilot targeted students whose Master's programmes commenced in September 2014. The initiative was limited to 12 institutions and ten specialties within them. The cross-programme access from the first to the second cycle was later made a countrywide policy in the new 'Law about Higher Education,' (2014, chapter 2).

The cross-programme access has not been the only arrangement needed to make the three-cycle system work in Ukraine. The civil sector organisations and institutions have been trying to clarify the meaning of the third cycle in Ukraine. Finikov (2012) and EACEA et al (2012) mention that a pilot project was initiated by the National University 'Kyiv-Mohyla Academy' to create its doctoral school to offer PhD programmes. The project was not encouraged by the Ministry and did not gain recognition in the country. It was perhaps because of the unclear status of the $\mathrm{PhD}$ degree back then, in relation to the two national research degrees. The examination of the website of this doctoral school (Doctoral School of Kyiv Mohyla Academy, 2010) suggests that the school was created in 2008. The work of the school became limited to offering professional development courses for those working towards obtaining the Doctor of Sciences degrees. There was an obvious association of $\mathrm{PhD}$ with Doctor of Sciences by this university. In addition, the equation of the Candidate of Sciences cycle in Ukraine with the Bologna PhD was long promoted by the National TEMPUS/ERASMUS Plus Office:

PhD is sort of in the middle between our Candidate of Sciences' degree and Doctor of Sciences. It is closer to the Candidate of Sciences, though, because of a similar duration of studies. Far more people here get Candidate of Sciences than Doctor of Sciences. So it is better to equate Candidate of Sciences to PhD. This means that more people will get a PhD. If we equate it to Doctor of Sciences, a lot of people won't get to PhD because not many people target to get the Doctor of Sciences' degree. People will do the Candidate of Science's degree, which is not recognised in Europe (i.2, TEMPUS Office representative).

\subsection{Five cycles in the three-cycle system}

The equation of the Candidate of Sciences degree with the $\mathrm{PhD}$, promoted by the National TEMPUS Office, was legalised in the new 'Law about Higher Education' (2014). 
In addition to the change in name of the third cycle made by the Law, the first and second cycles have also undergone changes.

The Law has left the Junior Specialist's degree in place, having renamed it into Junior Bachelor's. The Specialist's degree was canceled in the new 'Law about Higher Education' (2014, chapter 2, article 5). Hence, the Master's degree became the only degree in the second cycle. This change raises a question about how Specialist's diplomas, obtained earlier, will be dealt with by employers. The new Law has also substituted the Candidate of Sciences degree with the PhD degree. It is defined as a four-year programme of doing 'scientific, scientific-technical, scientific-pedagogical, scientific-organisational' work. While an explanation of the meanings of different types of this work is absent, it is clear that the PhD degree is 'obtained at the third cycle on the basis of a Master's degree...' The Doctor of Philosophy degree is awarded after successful completion of a relevant education-scientific programme and a public defense of a thesis with a special scientific council' ('Law about Higher Education,' 2014, chapter 2, article 5). The degree of Doctor of Sciences, according to the new Law, has been preserved. Its duration is undefined, but its requirements are provided. Doctor of Sciences presupposes 'mastering the highest competences in the field of the development and implementation of research, conducting original research, obtaining results that support the answer to an important theoretical or practical question' (chapter 2, article 5). It could be assumed that the specifics of this degree remained unchanged in comparison to how it worked before the new Law.

Clearly, the Law has preserved the two degrees that are lower than the second cycle - Junior Bachelor's and Bachelor's. It also kept the two degrees that are higher than Master's - PhD and Doctor of Sciences. However, the first and the third cycles, according to the Law, contain only one degree. Junior Bachelor's and Doctor of Sciences formed two separate cycles in addition to the three Bologna cycles. The Law states that Junior Bachelor's degree belongs to the initial cycle, Bachelor's - to the first cycle, Master's degree - to the second cycle, Doctor of Philosophy degree - to the third cycle, and Doctor of Sciences degree - to the scientific cycle (article 5). So the puzzle of implementing the three-cycle system without too many changes in the national system of degrees was resolved by confirming five cycles. The first and the last cycles fall beyond the three Bologna cycle system. The equation of one research cycle in Ukraine to the PhD cycle, the elimination of the Specialist's degree and the renaming of the Junior Specialist's into Junior Bachelor's were done through re-branding the old structures.

\section{Bologna study cycles and policy learning}

The findings above have shown how the Bologna study cycle instrument in Ukraine has been developed on the basis of the old national education-qualification and scientific cycles. The Bologna study cycles in Ukraine have been shaped by the higher 
education actors primarily by first providing new labels to old structures and then making minor changes to some of the old structures periodically.

The above finding has already pointed to the possibility of applying the ideas of the policy learning, such as path-dependence and layering in emerging innovations, to the discussion of the development of study cycles in Ukraine. The closing discussing below considers how features of layering in policy learning such as productivity and collectivism, introduced earlier in this article, apply in the Ukrainian case.

\subsection{Productivity of learning}

The study cycle reform in Ukraine has been happening though the accumulation of layers of innovations on top of old structures. Bologna study cycles in Ukraine have been evolving through the reconfiguration of the pre-Bologna policies. These old policies were at first chosen by the Ministry to represent the Bologna instrument - study cycles. However, new layers appeared. Each innovation in a way 'needed' previous layers to 'stand' on. A rough division among these layers and a relatively structured picture of their accumulation was illustrated in the previous section - first the old education-qualification

cycles and scientific cycles, then the two-cycle system, then the three-cycle system, and finally the five cycles the first and last one falling beyond the three-cycle system. Of course, such a separation of the series of layers was instrumental in this analysis. These layers are, indeed, quite muddled in reality.

This study has shown that different higher education actors in Ukraine found themselves in the middle of great uncertainty about how to deal with Bologna, especially at the beginning. These actors had to engage in a significant sense-making process. They took time to work out what was suggested in the international documents, and to understand how those ideas could be developed in the Ukrainian context. They could not just implement the action lines. They faced the necessity, and thus, an opportunity to actually interpret Bologna international ideas. This supports Freeman's (2006) argument about the meaning of learning. The author claims that policy learning 'is, in a fundamental way, about creating the world' (p. 382). He further argues that policy is 'generated rather than disseminated' (p. 379). This suggests that the productive nature of policy learning may be about the emergence of the meaning of policy through learning.

The development of Bologna study cycles in Ukraine was not just about reproduction of international ideas but rather about production of their extensions in the national context. The way the productive nature of learning was unfolding in the Ukrainian case is slightly different from what is suggested in the literature about policy uncertainty. The literature claims that the bigger the uncertainty, the more policy actors are active in seeking new knowledge. They need to explore examples of best practices of 
dealing with similar situations. This serves as a basis for policy actors to identify possible options to address the issues they face (Burch, 2007; Zarkin, 2008).

The opposite was the case in Ukraine. The lack of knowledge about Bologna in general and particularly about its study cycle instrument contributed to the fact that pathdependency was the strongest at the beginning of the reform process. At the outset of the Bologna process, the avoidance of changes by simply relabeling the old policies as the new Bologna instruments appears to have been consciously and deliberately exercised. It was particularly noticeable in terms of the Ministry. It issued multiple decrees to develop the Bologna study cycles mainly by changing labels for the old national policies.

This suggests that both path-dependency and change in learning should not be seen as constraints to each other, but rather as inherently interconnected creative powers, neither of which could be avoided in the Bologna reform. The preservation of the old conventions tends to be seen as a constraint for change in the literature that looks at the Bologna reform process in different countries, including Ukraine (e.g., Andreichuk, 2007; Pyykkö, 2008). This study, building on the idea of layering, suggests looking at policy continuity from a different perspective. Continuity does not appear here to be an obstacle to change. Previously established policies can be used as a basis for the introduction of slow changes. The Ukrainian case shows how it was the old that became the basis for the new. So continuity and change should not be viewed as two forces that pull the development in different directions. A more productive way to look at the role of policy continuity and change in the development of the Bologna reforms is to see these two processes as intertwined in shaping the reforms.

\subsection{Shared nature of learning}

The messy and creative learning in the reform of study cycles in Ukraine has been the result of contributions from different higher education actors. Thus, it generated a shared and more horizontal policy-making mode, or what some authors call governance (e.g., Enders, 2004). All these actors, in Freeman's (2006) terms, have been 'piecing together' the Bologna instruments. The actors have been increasingly constructing, interpreting and reinterpreting the meanings around the Bologna instruments. These developments were new to the previously highly centralized policy arena of Ukraine (Wolczuk, 2009).

Thus, a more shared policy-making in higher education in Ukraine began to emerge. Bologna has very slowly, yet steadily, been giving way to the development of governance in the higher education sector in Ukraine. The findings of this research suggest that such a distributed policy-making has not yet come to replace the traditional government mode in Ukraine, as the literature on contemporary policy-making in general suggests (Enders, 2004). This literature argues that we can witness a clear shift from 
government to governance in policy-making practices. The particular policy setting of Ukraine, with its still quite strong dependence on the Soviet centralisation legacy, indicates that the shared governing mode is only at its beginning.

\section{Conclusion}

This article has drawn upon the relevant literature, empirical research and analysis to explore how policy learning can be used as an analytical tool for studying the development process of the Bologna study cycles in the Ukrainian higher education context.

The Ukrainian case shows that policy learning can be viewed as a process that unfolds through the fluidity between path-dependency and innovations that mutually shape each other. Crucially, path-dependency and change become interlinked through productive and collective layering.

Ukraine had its own education-qualification and scientific cycles before Bologna. No radical transformations happened with the commencement of the Bologna process in the country. Policy learning has been apparently slow and gradual. Interestingly, the findings above have shown how the Bologna study cycles in Ukraine have been developed on the basis of the old national education-qualification and scientific cycles. The Bologna study cycles in Ukraine have been shaped by the higher education actors providing new labels to old structures and making minor changes to some of the old structures periodically. The following were significant layers in this policy learning process: the two-cycle system, then the three-cycle system, and then the three-cycle system with five cycles in it (the first and last one falling beyond the three-cycle system, but technically belonging to the three-cycle system). The findings also demonstrate that features such as layering as messiness, productivity and collectivism apply in the Ukrainian case. The layering in the development of the Bologna study cycles in Ukraine has been messy but at the same time quite productive as it was exercised jointly by multiple policy actors.

\section{References}

Alexiadou, N. (2014) 'Policy learning and Europeanisation in education: The governance of a field and the transfer of knowledge', in A. Nordin and D. Sundberg (eds). Transnational policy flows in European education: The making and governing of knowledge in the education policy field, Oxford: Symposium Books, pp. 123-140.

Andreichuk, S. K. (2007). Derzhavne upravlinnya reformuvannya vyshchoyi osvoty v Ukrayini $v$ koneksti Bolonskogo Protsesu [State management of higher education reform in Ukraine in the context of the Bologna Process] (Candidate of Sciences). Lviv Regional Institute of State Management, Lviv, Ukraine. Retrieved December 18, 2018, from 
http://irbis-nbuv.gov.ua/cgi-

bin/irbis64r_81/cgiirbis_64.exe?Z21ID=\&I21DBN=ARD\&P21DBN=ARD\&S21STN

$=1 \& S 21 \mathrm{REF}=10 \& S 21 \mathrm{FMT}=$ fullwebr $\& \mathrm{C} 21 \mathrm{COM}=\mathrm{S} \& S 21 \mathrm{CNR}=20 \& \mathrm{~S} 21 \mathrm{P} 01=0 \& \mathrm{~S} 21 \mathrm{P} 0$

$2=0 \& S 21 \mathrm{P} 03=\mathrm{A}=\& \mathrm{~S} 21 \mathrm{COLORTERMS}=1 \& \mathrm{~S} 21 \mathrm{STR}=\% \mathrm{D} 0 \% 90 \% \mathrm{D} 0 \% \mathrm{BD} \% \mathrm{D} 0 \% \mathrm{~B} 4 \%$

D1\%80\%D0\%B5\%D0\%B9\%D1\%87\%D1\%83\%D0\%BA\%20\%D0\%A1.\%D0\%9A.\$

Bennett, C. J. and Howlett M. (1992) 'The lessons of learning: reconciling theories of policy learning and policy change', Policy Sciences 25(3): 275-294.

Blaikie, N. W. H. (2000) Designing social research: the logic of anticipation, Cambridge, UK; Malden, MA: Polity Press.

Borrás, S. (2011) 'Policy Learning and Organisational Capacities in Innovation Policies', Science and Public Policy 38(9): 725-734.

Burch, P. 2007 'Educational Policy and Practice from the Perspective of Institutional Theory: Crafting a Wider Lens', Educational Researcher 36(2): 84-95.

Cairney, P. (2011) 'The New British Policy Style: From a British to a Scottish Political Tradition? The New British Policy Style', Political Studies Review 9(2): 208-220.

Chakroun, B. (2010) 'National Qualification Frameworks: From Policy Borrowing to Policy Learning', European Journal of Education 45(2): 199-216.

Corbett, A. (2011) 'Ping Pong: competing leadership for reform in EU higher education 1998-2006', European Journal of Education 46(1): 36-53.

Doctoral school at Kyiv-Mohyla Academy. (2010). Retrieved December 18, 2018, from https://www.ukma.edu.ua/index.php/science/gradschool

Dolowitz, D. P., and Marsh, D. (2000) 'Learning from abroad: the role of policy transfer in contemporary policy-making', Governance 13(1): 5-23.

Education, Audiovisual and Culture Executive Agency (EACEA), National TEMPUS

Office, \& Shytikova, S. (2012, July). Document "Higher education in Ukraine."

Retrieved December 18, 2018, from

http://eacea.ec.europa.eu/tempus/participating_countries/overview/ukraine_tem pus_country_fiche_final.pdf

Enders, J. (2004) ‘Higher Education, Internationalisation, and the Nation-state: Recent Developments and Challenges to Governance Theory', Higher Education 47(3): 361-382.

Finikov, T. (Ed.). (2012). Vhodzhennya natsionalnoyi systemy vyshchoyi osvity v Yevropeiskyi prostir vyshchoyi isvity ta naukovoho doslidzhennya [The integration of the national system of higher education into the European space of higher education and research]. Kyiv: Takson. Retrieved December 18, 2018, from

http://www.edupolicy.org.ua/files/Analit12_ua_.pdf 
Freeman, R. 2006. “Learning in Public Policy.” In M. Moran, M. Rein, \& R. E. Goodin (Eds.), The Oxford Handbook of Public Policy. Oxford; New York: Oxford University Press.

Freeman, R. (2007) 'Epistemological Bricolage: How Practitioners Make Sense of Learning', Administration and Society 39(4): 476-496.

Grin, J., and Loeber, A. (2007) 'Theories of Policy Learning: Agency, Structure, and Change', in F. Fischer, G. Miller, and M. S. Sidney (eds). Handbook of Public Policy Aanalysis: Theory, Politics, and Methods, Boca Raton: CRC/Taylor and Francis, pp. 201-222.

Haas, P. (2004) 'When does power listen to truth? A constructivist approach to the policy process', Journal of European Public Policy 11(4): 569-592.

Hall, P. (1993) 'Policy Paradigms, Social Learning, and the State: The Case of Economic Policymaking in Britain', Comparative Politics 25(3): 275.

Heikkilla, T., \& Gerlak, A. K. (2013). Building a conceptual approach to collective learning: lessons for public policy scholars: lessons for public policy scholars. Policy Studies Journal, 41(3), 484-512.

Koch, J., Eisend, M., and Petermann, A. (2009) 'Path dependence in decision-making processes: exploring the impact of complexity under increasing returns', $B u R$ Business Research 2(1): 67-84.

Kremen, V., Nikolajenko, S., Stepko, M., \& European Centre for Higher Education (UNESCO). (2006). Higher education in Ukraine. Bucharest: UNESCO-CEPES.

Lange, B., and Alexiadou, N. (2010) 'Policy learning and governance of education policy in the EU', Journal of Education Policy 25(4): 443-463.

Levin, B. (2010) 'An epidemic of education policy:(what) can we learn from each other?', Comparative Education 34(2): 131-141.

Lingard, B. (2010) 'Policy borrowing, policy learning: Testing times in Australian schooling', Critical Studies in Education 51(2): 129-147.

March, J. G., and Olsen, J. P. (1989) Rediscovering Institutions: The Organisational Basis of Politics, New York: The Free Press.

Marsh, D., and Sharman, J. C. (2009) 'Policy Diffusion and Policy Transfer', Policy Studies 30(3): 269-288.

May, P. (1992) 'Policy Learning and Failure', Journal of Public Policy 12(4): 331-354.

Merriam, S. B. (2009) Qualitative research: a guide to design and implementation, San Francisco: Jossey-Bass.

Peck, J. (2011) 'Geographies of Policy: From Transfer-diffusion to Mobility-mutation', Progress in Human Geography 35(6): 773-797.

Pyykkö, R. (2008). Bachelors for Europe, specialisty for the fatherland: Bologna through Russian eyes. Slavica Helsingiensia, 35, 331-337. 
Radaelli, C. M., and Dunlop, C. A. (2013) 'Learning in the European Union: Theoretical Lenses and Meta-theory', Journal of European Public Policy 20(6): 923-940.

Raffe, D., and Semple, S. (2011) Policy Borrowing Or Policy Learning?: How (not) to Improve Education Systems, Edinburgh: Centre for Educational Sociology.

Rubin, H. J., and Rubin, I. (2012) Qualitative interviewing: the art of hearing data (3rd ed), Thousand Oaks, CA: Sage.

Sabatier, P. A. and Jenkins-Smith, S. (1999). The advocacy coalition framework: an assessment. In Theories of the Policy Process, ed. P A Sabatier. Boulder, CO: Westview Press.

Schmidt, V. A. (2010) 'Taking ideas and discourse seriously: explaining change through discursive institutionalism as the fourth "new institutionalism"', European Political Science Review 2(1): 1-25.

Steiner-Khamsi, G. (2002) ‘Reterritorialising Educational Import: Explorations into the Politics of Educational Borrowing', in A. Nóvoa and M. Lawn (eds). Fabricating Europe. The formation of an education space, Dordrecht: Springer, pp.69-86.

Steiner-Khamsi, G. (2004) 'Conclusion: Blazing a Trail for Policy Theory and Practice', in The global politics of educational borrowing and lending, New York: Teachers College Press, pp. 201-217.

Steiner-Khamsi, G. (2006) 'The Economics of Policy Borrowing and Lending: A Study of Late Adopters', Oxford Review of Education 32(5): 665-678.

Stone, D. (2012) 'Transfer and Translation of Policy', Policy Studies 33(6): 483-499.

Talanova, Z. (2014). Vprovadzhennya tryoh tsykliv vyshchoyi osvity [The implementation of three cycles of higher education]. In V. Luhovy \& Kalashnikova (Eds.), Pravovi zasadu realizaciyi Bologskogo Protsesu v Ukrayini [Legal basis of the implementation of the Bologna Process in Ukraine]. Kyiv: DP NVTS Prioritety. Retrieved December 18, 2018, from http://www.irf.ua/knowledgebase/publications/pravovi_zasadi_realizatsii_bolon skogo_protsesu_v_ukraini/

Thelen, K. (2003) ‘How Institutions Evolve: Insights from Comparative Historical Analysis', in J. Mahoney and D. Rueschemeyer (eds). Comparative historical analysis in the social sciences, Cambridge, U.K: Cambridge University Press, pp. 208-240.

Trowler, P. (2001) 'Introduction: Higher Education Policy, Institutional Change', Higher educational policy and institutional change: intentions and outcomes in turbulent environments, Buckingham: Open University Press, pp. 13-35.

Wolczuk, K. (2009). Implementation without coordination: the impact of EU conditionality on Ukraine under the European Neighbourhood Policy. EuropeAsia Studies, 61(2), 187-211. 
Zarkin, M. J. (2008) ‘Organisational Learning in Novel Policy Situations: Two Cases of United States Communications Regulation', Policy Studies 29(1): 87-100.

\section{Appendix 1}

\section{List of policy documents}

Bergen Communiqué (2005) Retrieved 9 August 2015 from http://www.ehea.info/Uploads/Declarations/Bergen_Communique1.pdf

Berlin Communiqué (2003) Retrieved 9 August 2015 from http://www.ehea.info/Uploads/Declarations/Berlin_Communique1.pdf

Bologna Declaration (1999) Retrieved 9 August 2015 from http://www.magnacharta.org/resources/files/BOLOGNA_DECLARATION.pdf

Bologna Process Stocktaking Report (2012) Retrieved 9 August 2015 from http://www.ehea.info/Uploads/\%281\%29/Bologna\%20Process $\% 20 I m p l e m e n t a t i o n \% 20 R e$ port.pdf

Law about education (1991) Retrieved 9 August 2015 from http://zakon2.rada.gov.ua/laws/show/1060-12

Law about higher education (2002) Retrieved 9 August 2015 from http://zakon4.rada.gov.ua/laws/show/2984-14

Law about higher education (2014) Retrieved 9 August 2015 from http://zakon4.rada.gov.ua/laws/show/1556-18

Law about scientific and scientific-technical work (1992) Retrieved 9 August 2015 from http://zakon2.rada.gov.ua/laws/show/1977-12

London Communiqué (2007) Retrieved 9 August 2015 from http://www.coe.int/t/dg4/highereducation/ehea2010/London\%20Communique\%20\%2018-05-2007.pdf

Ministerial decree №48 'About a pedagogical experiment on the credit-module system of the organisation of the study process' (2004) Retrieved 9 August 2015 from https://www.google.com.ua/url?sa=t\&rct=j\&q=\&esrc=s\&source=web\&cd=1\&cad=rja\&ua $\mathrm{ct}=8 \&$ ved=0CBwQFjAAahUKEwj_mt_asZzHAhVGVSwKHVGhDWY\&url=http $\% 3 \mathrm{~A} \% 2$ F\%2Fold.mon.gov.ua\%2Fimages\%2Ffiles\%2Fosvita\%2FEvrointehraciya\%2Fmon_48.doc \&ei $=\mathrm{cX} v \mathrm{HVb}-$ eG8aqsQHRwrawBg\&usg=AFQjCNF4jX4JOyHhKQ1TZWAV7KuMWY14kA\&sig2=HQX I36SqDiVMGZY2_h48Hw\&bvm=bv.99804247,d.bGg

Ministerial decree №49 'About the confirmation of the programme of actions related to the implementation of the ideas of the Bologna declaration in the system of 
higher education and science of Ukraine for 2004-2005' (2004) Retrieved 9 August 2015 from

https://www.google.com.ua/url?sa=t\&rct=j\&q=\&esrc=s\&source=web\&cd=1\&cad=rja\&ua ct=8\&ved=0CBwQFjAAahUKEwiynZ6OuZzHAhVBjCwKHbSLCp4\&url=http\%3A\%2F \%2Fiic.dgtu.donetsk.ua\%2Frussian\%2Fovs\%2Fprik_2.doc\&ei=NIPHVbKzHcGYsgG016r wCQ\&usg=AFQjCNEsSfBYF3Ot-AhEBWjmzNN7gTSIAA\&sig2=u4Im-FkySjOMepLF6i4JA\&bvm=bv.99804247,d.bGg

Ministerial decree №548 'About conducting a pilot project at higher education establishments, subordinated to the Ministry, regarding obtaining the educationqualification level of Master's on the basis of Bachelor's in a different study field' (2013) Retrieved 9 August 2015 from http://osvita.ua/legislation/Vishya_osvita/36244/

Ministerial decree №612 'About the confirmation of the plan of actions related to quality assurance in higher education of Ukraine and its integration into the European and global education society for the period until 2010' (2007) Retrieved 9 August 2015 from http://elib.crimea.edu/zakon/min612.pdf

Salzburg Principles (2005) Retrieved 9 August 2015 from http://www.vsnu.nl/files/documenten/Domeinen/Onderzoek/2013\%20PHD\%20conferen ce/130215\%20-\%20Salzburg-principles-2005.pdf

\section{List of interviewees}

1. Higher education reform expert at the National TEMPUS office, instructor at higher education institution A;

2. National TEMPUS Office representative;

3. Ex-member of a working group of the Parliamentary Committee of Education and Science Matters, ex-member of the Bologna Follow-up Group, head of department at higher education institution $\mathrm{B}$;

4. Representative of the Fund Demokratychni Initsiatyoy. 